\title{
Relationship of staphylococcal toxins and enzymes with serological and phage types
}

\author{
K. K. CHOUDHURI ${ }^{1}$ AND A. N. CHAKRABARTY ${ }^{2}$ \\ From the Department of Pathology and Bacteriology, Institute of Post-Graduate Medical Education \\ and Research, Calcutta, India
}

SYNOPSIS A study has been made of 523 strains of staphylococci on the basis of biological properties, phage typing, and serology. The value of serology in the identification of pathogenic staphylococci has been assessed.

The recognized parameters of pathogenicity of staphylococci such as coagulase production or pathogenicity in animals are known to have a high degree of correlation with their toxigenic and enzymatic composition. The pathogenic staphylococci are also susceptible to the typing phages used (Blair, 1962; Fisk, 1942). The method of division of staphylococci into serological types is yet another approach to the classification of these organisms (Cowan, 1938 and 1939; Christie and Keogh, 1940; Hobbs, 1948). This method may be of importance for the subdivision of coagulase-negative, phage-insensitive staphylococci. On the basis of his comprehensive studies on Gram-positive, catalase-positive cocci, Baird-Parker (1963 and 1965) proposed a classification of these organisms into three genera, namely, Staphylococcus, Micrococcus, and Sarcina; the genus Staphylococcus could be further divided into seven subgroups. The subgroup I accommodated coagulase-positive organisms associated with human pathological lesions. The organisms of subgroup II were encountered from human and pig surfaces, and were coagulasenegative. But in view of the biological and technical limitations of the coagulase test, he considered it inadvisable to rely solely on this test for the identification of Staphylococcus aureus. In the present study some coagulase-negative strains isolated from human pathological sources were examined from the point of view of a possible association of certain serotypes with their capacity to produce known toxins and enzymes.

${ }^{1}$ Present address: Department of Pathology and Bacteriology, Medical College, Calcutta-12.

'Present address: Division of Microbiology, Jadavpur University, Calcutta-32.

Received for publication 15 August 1969.

\section{Materials and Methods}

Five hundred and twenty-three staphylococcal strains were isolated from clinical lesions of in- and outpatients of a Calcutta hospital. The strains were tested for coagulase, hyaluronidase, alpha, beta, and delta haemolysins, lipase, gelatinase, and phosphatase activities and Müller's phenomenon, according to the methods reviewed by Elek (1959), except for leucocidin and fibrinolysin, which were detected according to the methods as described by McLeod (1963) and Vogelsang, Wormnes, and Östervold (1962) respectively. Phage typing was done according to the method of Blair and Williams (1961), using the basic set. Serological typing of the coagulase-negative strains was determined following the method described by Stern and Elek (1957), using Cowan's type I, II, and III strains (NCTC nos. 8530, 8531, and 8532 respectively).

\section{Results}

ASSOCIATION OF DIFFERENT TOXINS AND ENZYMES AND OTHER BIOLOGICAL CHARACTERS WITH COAGULASE-POSITIVE STAPHYLOCOCCI ISOLATED FROM HUMAN LESIONS

Out of a total of 523 strains studied 502 were coagulase-positive and the rest negative. The incidence rate of various toxins and enzymes among the former were as follows: phosphatase $(98.4 \%)$, mannitol $(97.6 \%)$, and glucose fermentations $(95.9 \%)$; gelatinase $(95.4 \%)$, leucocidin 


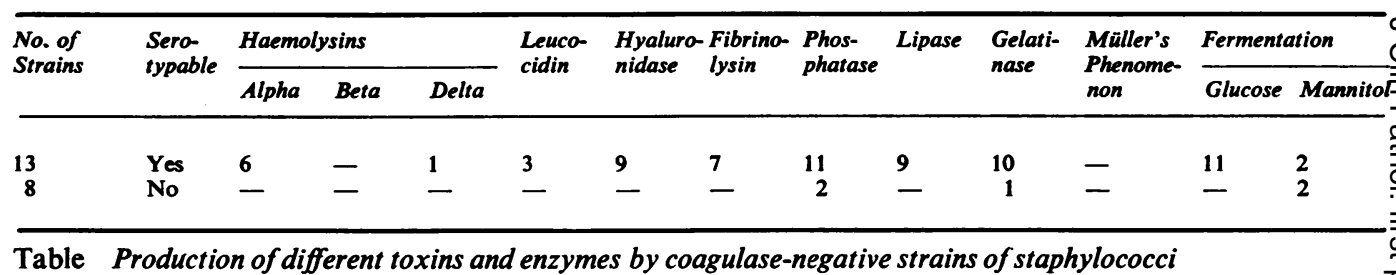

Table Production of different toxins and enzymes by coagulase-negative strains of staphylococci

(92.4\%), Müller's phenomenon (91.6\%), hyaluronidase $(91 \cdot 2 \%)$, alpha haemolysin $(90.2 \%)$, lipase $(81.4 \%)$, and beta-haemolysin $(16.1 \%)$. It appeared that the frequency of occurrence of the individual biological characters was a variable feature of this group.

\section{ASSOCIATION OF COAGULASE-NEGATIVE STRAINS WITH THE DIFFERENT TOXINS AND ENZYMES}

The association of various toxins, enzymes, and other biological characters with 21 coagulasenegative strains was studied and found to be as follows: alpha haemolysin $(42 \cdot 8 \%)$, fibrinolysin $(33.3 \%)$, phosphatase $(33.3 \%)$, lipase $(42.8 \%)$, gelatinase $(52 \cdot 3 \%)$, mannitol $(61.9 \%)$ and glucose fermentations $(9.5 \%)$, delta haemolysin $(4.7 \%)$, and leucocidin $(14.2 \%)$. These strains had neither beta-haemolysin nor exhibited Müller's phenomenon.

\section{CORRELATION OF DIFFERENT BIO-}

LOGICAL CHARACTERS WITH SEROLOGICAL TYPES OF THE 21 COAGULASE-NEGATIVE STRAINS

The 13 coagulase-negative but serologically typable strains exhibited a distribution pattern of toxins and enzymes somewhat similar to that of the coagulase-positive strains. The relationship of these products with toxins and enzymes of coagulase-positive staphylococci was demonstrated by their neutralization with specific staphylococcal antitoxins prepared for this purpose (Table). On the other hand, the remaining eight coagulase-negative, serologically non-typable strains exhibited little capacity to elaborate these biological products. Of these 13 coagulase-negative sero-typable strains, six belonged to group I, five to group II, and two to group III in the Cowan classification (1939).

RELATIONSHIP OF THE DIFFERENT BIOLOGICAL CHARACTERS WITH THE STAPHYLOCOCCAL PHAGE TYPES

The 21 coagulase-negative strains were all non-typable with the basic set of phages. Of the remaining 502 strains, those belonging to phage group I had the highest correlation with gelatinase activities (100\%), group II the highest correlation with gelatinase and phosphatase activities (100\%), group III with phosphatase
$(98 \%)$, the mixed type with delta haemolysin $\frac{\bar{c}}{\bar{c}}$ and gelatinase $(100 \%)$, and the non-typable variety with phosphatase $(100 \%)$.

\section{Discussion}

There is very little doubt about the pathogenici status of staphylococci that are coagulase $-\omega$ positive and which, in addition, possess theic capacity to produce many other toxins and $\delta$ enzymes together with phage susceptibility. Be-O sides this clear-cut group, there are others whichare encountered in pathological materials fromz human cases, and the status of these organismse in relation to the previous group as well as their pathogenicity needs to be assessed. Studies of numerous workers (Elek, 1959) on the association of single or groups of characters with staphy-o lococci considered to be pathogenic, either ons account of the clinical history and nature of the lesion, or based on the results of animap pathogenicity, appear to have been carried out with? a view to using the highly correlative characters $\overrightarrow{\vec{O}}$ as nearly equivalent substitutes for the more 3 difficult proof of staphylococcal pathogenicity In such an approach, in the absence of a character. as important as coagulase production, othero highly correlative characters may be relied: upon.

The present studies showed that a high butio varying percentage of coagulase-negative buţ sero-typable strains produced enzymes and toxinso which were comparable to those of the coagulase positive strains. In contrast, the coagulase-negativeo serologically untypable strains elaborated very few enzymes and toxins, and the pathogenicityos of these strains, in spite of their isolation from human pathological sources, remains doubtful. N

The study of the different phage groups with the biological characteristics of staphylococce showed that phage group I had the highes $\mathrm{K}_{\mathrm{O}}$ correlation with leucocidin, hyaluronidase, gelas tinase, and Müller's phenomenon, which is in agreement with the observations of Fodor, Rozgonyi, and Csépke (1963) and Tauraso and White (1963). The finding in respect of phages group II having maximum correlation with alpha and beta haemolysins, lipase and phosphatase, and phage group III with fibrinolysin, and theo mixed type with the delta haemolysin, does not support the observations of Solomon and Sano Clemente (1963) or Cannon and Hawn (1963) 
It appears, therefore, that studies on the composite nature of biological characters of staphylococci are helpful in evaluating the status of coagulase-negative staphylococci. The serotyping is an additional adjunct in such a situation.

We wish to thank the Director of the Institute of Post-Graduate Medical Education and Research for the facilities provided for the research work. The three Cowan type strains were obtained through the courtesy of Dr S. P. Lapage, CPHLS, Colindale, London.

\section{References}

Baird-Parker, A. C. (1963). A classification of micrococci and staphylococci based on physiological and biochemical tests. J. gen. Microbiol., 30, 409-427.

Baird-Parker, A. C. (1965). The classification of staphylococci and micrococci from world-wide sources. J. gen. Microbiol., 38, 363-387.

Blair, J. E. (1962). What is a staphylococcus? Bact. Rev., 26, 375-381.

Blair, J. E., and Williams, R. E. (1961). Phage typing of staphylococci. Bull. Wld. Hlth. Org., 24, 771-784.

Cannon, F. D., and Hawn, C. V. Z. (1963). Phosphatase activity of Staphylococcus aureus: correlation of enzyme production with resistance to penicillin and phage pattern. J. Bact., 86, 1052-1056.
Christie, R., and Keogh, E. V. (1940). Physiological and sero logical characteristics of staphylococci of human origin $\Omega$ J. Path. Bact., 51, 189-197.

Cowan, S. T. (1938). The classification of staphylococci by precipitation and biological reactions. J. Path. Bact., 460 $31-45$.

Cowan, S. T. (1939). Classification of staphylococci by slide agglutination. J. Path. Bact., 48, 169-173.

Elek, S. D. (1959). Staphylococcus pyogenes and its Relation t Disease. Livingstone, Edinburgh.

Fisk, R. T. (1942). Studies on staphylococci. J. infect. Dis., 719 153-165.

Fodor, M., Rozgonyi, F., and Csépke, E. (1963). Correlatio믐 between phage-type, coagulase, hyaluronidase an phosphatase activity, and mercuric chloride resistance of Staphylococcus aureus. Acta microbiol. Acad. Sci. hung., 10 , 19-25.

Hobbs, B. C. (1948). A study of the serological type differentiation of Staphylococcus pyogenes. J. Hyg. (Lond.), 46, 222-238

McLeod, J. W. (1963). Thermostatic staphylococcal toxin. J. Path. Bact., 86, 35-53.

Solomon, J. J., and San Clemente, C. L. (1963). Some physiow logical characteristics of two sets of phage-propagatin strains of Staphylococcus aureus. Appl. Microbiol., 10 36-41.

Stern, H., and Elek, S. D. (1957). Antigenic structure of Staphy lococcus pyogenes. J. Path. Bact., 73, 473-483.

Tauraso, N. M., and White, D. A. (1963). Studies on staph lococcal infections. Amer. J. Dis. Childh., 105, 164-174.

Vogelsang, T. M., Wormnes, A., and Östervold, B. (1962\% Correlation between staphylococcal phage groups an\$ some staphylococcal enzymes demonstrated by simple methods. Acta path. microbiol. scand., 54, 218-224.

\section{Reports and Bulletins prepared by the Association of Clinical Biochemists}

The following reports and bulletins are published by the Asscciation of Clinical Biochemists. They may be obtained from The Administrative Office, Association of Clinical Biochemists, 7 Warwick Court, Holborn, London, W.C.1. The prices include postage, but airmail will be charged extra. Overseas readers should remit by British Postal or Money Order. If this is not possible the equivalent of 10s. is the minimum amount that can be accepted.

\section{SCIENTIFIC REPORTS}

3 Automatic Dispensing Pipettes. An assessment of 35 commercial instruments 1967 P. M. G. BROUGHTON, A. H. GOWENLOZK, G. M. WIDDOWSON, and $\mathrm{K}$. A. AHLQUIST $17 \mathrm{~s}(\$ 2)$

4 An Evaluation of 5 Commercial Flame Photometers suitable for the Simultaneous Determination of Sodium and Potassium March 1970 P. M. G. BROUGHTON and J. B. DAWSON 17s (\$2)

TECHNICAL BULLETINS

9 Determination of Urea by AutoAnalyzer November 1966 RUTH M. HASLAM 8s 6d (\$1)

10 Filter Fluorimeters. A comparative list of 14 instruments March 1967 HANNELORE BRAUNSBERG (Re-issued in response to demand. Text still valuable, list now out of date) $8 \mathrm{~s} 6 \mathrm{~d}(\$ 1)$
11 Determination of Serum Albumin by AutoAnalyzer using Bromocresol Green October 1967 B. E. NORTHAM and G. M. WIDDOWSON 8s 6d (\$1)

13 An assessment of the Technicon Type II Sampler Unit March 1968 B. C. GRAY and G. K. MCGOWAN 8s 6d (\$1)

14 Atomic Absorption Spectroscopy. An outline of its Principles and a Guide to the Selection of Instruments May 1968 J. B. DAWSON and P. M. G. BROUGHTON $8 \mathrm{~s} 6 \mathrm{~d}(\$ 1)$

15 A Guide to Automatic Pipettes (2nd edition) June 1968 P. M. G. BROUGHTON 8s 6d (\$1)

16 A Guide to Automation in Clinical Chemistry May 1969 P. M. G. BROUGHTON $12 \mathrm{~s} 6 \mathrm{~d}(\$ 1.50)$
17 Flame Photometers (2nd edition) 1969 P. WILDING 12s 6d (\$1.50)

18 Control Solutions for Clinical Biochemistry (4th edition) March 1970 P. M. G. BROUGHTON $12 \mathrm{~s} 6 \mathrm{~d}(\$ 1.50)$

19 Spectrophotometers. A comparative list of low-priced Instruments Readily Available in Britain May 1970 C. E. WILDE and P. SEWELL $12 \mathrm{~s} 6 \mathrm{~d}(\$ 1.50)$ 